\title{
EVALUASI PENGELOLAAN DANA DESA DENGAN INSTRUMEN DIMENSI PENGUKURAN PENGELOLAAN DANA DESA (DP2D2) BERDASARKAN UNDANG-UNDANG NOMOR 6 TAHUN 2014
}

\author{
Victor P. K. Lengkong, Hizkia H. D. Tasik
}

Fakultas Ekonomi dan Bisnis, Universitas Sam Ratulangi

A R T IC LE IN FO

\author{
Keywords : the village Fund; Dimensional \\ Measurements; Management and use; \\ Misappropriation of
}

\author{
Kata Kunci : \\ dan Penggunaan; Penyelewengan \\ Corresponding author : \\ Victor P. K. Lengkong \\ vpk.lengkong@gmail.com
}

Dana Desa; Dimensi Pengukuran; Pengelolaan

\begin{abstract}
Abstrack : The study of designing and assessing 4 dimensions of the village Fund, namely financial management, Infrastructure Development, community empowerment, and Abuses with such total highest value is 4. The results showed that the first dimension in the Regency of Minahasa has the highest score with a value of 2.75 , followed by the Regency of Minahasa in North and South Minahasa each with a score of 2.54 and 2.53. On the dimension of the development of Infrastructure (Sarpras) village, seen that the village Fund tend to be focused on funding the construction of the Sarpras transport. On the dimension of community empowerment, the villages are examined less fund the community empowerment program. Villages in the Regency of Minahasa in North only records the score 1.75 1.76, Minahasa Selatan, Minahasa and 2.03. On the dimensions of the aberration was recorded there are 8 villages taking the village Fund to fund programs that are a priority or in the existing provisions.
\end{abstract}

Abstrak : Penelitian ini merancang dan menilai 4 dimensi dana desa yaitu Pengelolaan Keuangan, Pembangunan Sarana Prasarana, Pemberdayaan Masyarakat, dan Penyelewengan dengant total nilai tertinggi adalah 4. Hasil penelitian menunjukkan bahwa pada dimensi pertama Kabupaten Minahasa memiliki skor tertinggi dengan nilai 2,75, diikuti Kabupaten Minahasa Utara dan Minahasa Selatan dengan skor masing-masing 2,54 dan 2,53. Pada dimensi Pembangunan Sarana Prasarana (Sarpras) Desa, terlihat bahwa Dana Desa cenderung difokuskan untuk pendanaan pembangunan Sarpras Transportasi. Pada dimensi Pemberdayaan Masyarakat, desa-desa yang diteliti kurang mendanai program pemberdayaan masyarakat. Desa-desa di Kabupaten Minahasa Utara hanya mencatatkan skor 1,76, Minahasa Selatan 1,75, dan Minahasa 2,03. Pada Dimensi Penyelewengan tercatat ada 8 desa yang memakai Dana Desa untuk mendanai program yang tidak menjadi prioritas ataupun yang masuk dalam ketentuan yang ada. 


\section{Latar Belakang}

\section{PENDAHULUAN}

Pemerintah Indonesia mengandalkan alokasi transfer ke daerah dan dana desa dalam membangun Indonesia. Dalam upaya membangun desa, mengeluarkan Undang-Undang Nomor 6 tahun 2014 untuk mengatur program Dana Desa. Penyaluran dana desa telah dimulai sejak tahun 2015 dengan besaran 3,23 persen dari dan di luar dana Transfer Daerah (atau on top) yang dialokasikan di dalam Anggaran Pendapatan dan Belanja Negara (APBN) yang kemudian meningkat menjadi 6 persen di tahun 2016 dan 10 persen di tahun 2017. Artinya, pada tahun 2015 dana desa berjumlah Rp 21,7 triliun, naik menjadi Rp 46,9 triliun di tahun 2016 dan kemudian naik menjadi Rp 60 triliun di tahun 2017 untuk lebih dari 74 ribu desa di Indonesia.

Sejak dimulainya program Dana Desa, pemerintah dan masyarakat mengutarakan begitu banyak harapan yang di antaranya adalah untuk menjaga dan meningkatkan daya beli masyarakat serta untuk membangun infrastruktur ${ }^{1}$ dan sektor padat karya yang bisa langsung berdampak pada ekonomi dan kesejahteraan masyarakat desa. $^{2}$ Penciptaan lapangan kerja diharapkan akan lebih meningkat seiring meningkatnya dana desa. Program ini juga diharapkan dapat menjadikan desa sebagai pilar penting dalam mengatasi masalah kemiskinan, kesenjangan, dan ketertinggalan.

Namun, ada beberapa hal yang menarik perhatian. Berdasarkan hasil Survei Sosial Ekonomi Nasional (Susenas) pada Maret 2016, angka kemiskinan di pedesaan justru meningkat menjadi 14,11 persen dari 14,09 persen (berdasarkan Susenas September 2015). Hal ini kontradiksi dengan adanya peningkatan dana desa di tahun yang sama. Ekonomi Indonesia pada tahun 2015 tumbuh 4,79 persen justru melambat bila dibanding tahun 2014 sebesar 5,02 persen. Jika jumlah dana desa tahun 2015 sebesar Rp. 20,7 triliun (setara 0,18 persen dari PDB) dibandingkan dengan dampak kontribusi terhadap PDB sebesar 0,09 persen, ini berarti terjadi masih adanya decreasing return to scale pada tahun yang sama yang harus diwaspadai pada tahun-tahun selanjutnya.

Secara umum, sejak program Dana Desa dijalankan tahun 2015, begitu banyak permasalahan yang yang terekam di antaranya adanya pemotongan dari pemerintah kabupaten seperti di Jawa Timur; ${ }^{3}$ penyimpangan dana desa seperti di NTT; ${ }^{4}$ masalah administratif seperti birokrasi penyaluran dana yang berbelit serta pelaporan dan pertanggungjawaban yang kurang lengkap ${ }^{5}$ atau tidak lengkapnya dokumen yang disyaratkan seperti Peraturan Bupati, Anggaran Pendapatan Belanja Daerah (APBD) dan Desa (APBDes), dan Rancangan Pembangunan Jangka Menengah (RPJM) desa ${ }^{6}$ yang memuat peraturan dan petunjuk teknis pengelolaan keuangan desa; ${ }^{7}$ kurangnya pengetahuan dalam pengelolaan dana serta minimnya kualitas sumber daya manusia; ${ }^{8}$ kurangnya pendampingan dan kualitas pendamping ${ }^{9}$; dan minimnya pengawasan dalam pengelolaan keuangan desa. ${ }^{10}$

Penelitian ini untuk mengidentifikasi permasalahan yang sebenarnya yang ada seputar pengelolaan dan penggunaan dana desa di tingkat desa dan kabupaten di beberapa kabupaten di Sulawesi Utara yang hingga saat ini belum menjadi perhatian khusus.

\footnotetext{
${ }^{1}$ http://www.bbc.com/indonesia/berita_indonesia/2015/09/150909_indonesia_dana_desa_ekonomi

${ }^{2}$ http://www.cnnindonesia.com/nasional/20151226200707-20-100472/jokowi-minta-kades-gunakan-dana-desa-untuksektor-padat-karya/

${ }^{3}$ http://news.liputan6.com/read/2843338/kpk-gandeng-kemendes-awasi-dana-desa

${ }^{4}$ http://news.liputan6.com/read/2665818/kpk-banyak-terima-laporan-penyimpangan-dana-desa

${ }^{5}$ http://manadopostonline.com/read/2016/01/13/Fantastis-Dana-Desa-Sulut-911-M/11932/2

${ }^{6}$ https://kominfo.go.id/index.php/content/detail/7386/sektor-infrastruktur-prioritas-penggunaan-dana-desa2016/0/artikel_gpr

${ }^{7}$ http://www.antaranews.com/berita/501199/kpk--ada-14-potensi-permasalahan-dana-desa

${ }^{8}$ http://www.pikiran-rakyat.com/jawa-barat/2016/10/30/hindari-penyimpangan-bpk-perketat-pengawasan-dana-desa383464

${ }^{9}$ http://manadopostonline.com/read/2015/04/10/Mei-106-Pengelolah-Dana-Desa-Direkrut/8547

${ }^{10}$ http://kupang.tribunnews.com/2016/04/08/masalah-pengelolaan-keuangan-desa dan http://www.koransindo.com/news.php? $r=5 \& n=89 \&$ date $=2016-03-25$
} 


\section{TINJAUAN PUSTAKA}

Berdasarkan Kementerian Desa, Pembangunan Daerah Tertinggal dan Transmigrasi Republik Indonesia (2016), Dana Desa (DD) adalah dana yang bersumber dari APBN yang diperuntukkan bagi Desa dan ditransfer melalui APBD Kabupaten/Kota setiap tahun, untuk membiayai penyelenggaraan kewenangan Desaberdasarkan hak asal usul, dan kewenangan lokal skala Desa.Setiap tahun Desa akan mendapatkan Dana Desa (DD) dari Pemerintah Pusat yang penyalurannya dilakukan melalui kabupaten/kota. Dana Desa merupakan mandat UU No. 6 Tahun 2014 tentang Desa, dialokasikan dalam bentuk transfer, bukan berbentuk proyek. Selama UU Desa berlaku maka DD akan terus menerus dialokasikan oleh Pemerintah.Besaran Dana Desa (DD) adalah 10 persen (10\%) dari dan di luar dana Transfer Daerah (atau on top) yang dialokasikan di dalam Anggaran Pendapatan dan Belanja Negara (APBN) secara bertahap.

Berdasarkan Peraturan Menteri Desa, Pembangunan Daerah Tertinggal, dan Transmigrasi Nomor 21 tahun 2015 disebutkan bahwa prioritas penggunaan Dana Desa tahun 2016 adalah untuk bidang Pembangunan Desa dan bidang Pemberdayaan Masyarakat Desa.Namun melalui rapat kabinet dan pernyataan langsung, Presiden Republik Indonesia Joko Widodo lebih menegaskan bahwa penggunaan Dana Desa tahun 2016 adalah untuk pembangunan infrastruktur dasar di Desa, dan pelaksanaannya dilakukan secara padat karya dan swakelola. Alokasi Dasar yang akan dibagi rata kepada seluruh Desa adalah sebesar 90 persen. Sedangkan Alokasi Proporsional yang dihitung dengan memperhatikan jumlah penduduk, angka kemiskinan, luas wilayah, dan tingkat kesulitan geografis sebesar 10 persen.

Seperti tahun 2015, Dana Desa disalurkan oleh Pemerintah kepada kabupaten/kota dengan cara pemindahbukuan dari Rekening Kas Umum Negara (RKUN) ke Rekening Kas Umum Daerah (RKUD). Selanjutnya Dana Desa disalurkan oleh Kabupaten/Kota kepada Desa dengan cara pemindahbukuan dari RKUD ke rekening kas Desa paling lambat 7 (tujuh) hari kerja setelah diterima di kas Daerah. Untuk tahun anggaran 2016, penyaluran Dana Desa berdasarkan pada Peraturan Menteri Keuangan (PMK) nomor 49 tahun 2016. Pasal 14 ayat 2 PMK 49/2016 menyatakan bahwa penyaluran Dana Desa dilakukan secara dua tahap, yaitu: Tahap I pada bulan Maret 2016 (60\%) dan Tahap II pada bulan Agustus 2016 (40\%).

Dana Desa disalurkan (ditransfer) ker rekening daerah dan tidak langsung ke rekening kas desa, susuai dengan perintah UU N0. 6/2014 tentang Desa. Penjelasan pasal 72 ayat (2) huruf b menyatakan bahwa yang dimaksud dengan "Anggaran bersumber dari Anggaran Pendapatan dan Belanja Negara tersebut (yang saat ini disebut Dana Desa)" adalah anggaran yang diperuntukkan bagi Desa dan Desa Adat yang ditransfer melalui Anggaran Pendapatan dan Belanja Daerah Kabupaten/Kota yang digunakan untuk membiayai penyelenggaran pemerintahan, pembangunan, serta pemberdayaan masyarakat, dan kemasyarakatan.

Pada tahun anggaran 2015 penyaluran Dana Desa dilakukan 3 kali, yaitu pada bulan april (40\%), Agustus (40\%) dan Oktober (20\%). Penyaluran pada tahap ketiga dilakukan di akhir tahun. Dalam prakteknya, karena terjadi transisi kelembagaan dan peraturan di tingkat pusat, penyaluran Dana Desa untuk TA 2015 memang terlambat. Sementara pada tahun anggaran 2016 penyaluran Dana Desa berdasarkan pada PMK nomor 49 tahun 2016. Pasal 14 ayat 2 PMK 49/2016 menyatakan bahwa penyaluran Dana Desa dilakukan dua tahap yaitu: Tahap I pada bulan Maret 2016 (60\%) dan Tahap II pada bulan Agustus 2016 (40\%). Dengan demikian untuk TA 2016, sebagian besar Dana Desa sudah terkirim di awal tahun.

Sesuai dengan PP No. 60/2014 dan Peraturan Menteri Desa PDTT No. 5/2015 jo No. 21/2015:

1. Dana Desa diprioritaskan untuk mendanai pembangunan Desa dan pemberdayaan masyarakat yang menjadi kewenangan dan tanggungjawab Desa.

2. Dana Desa diutamakan untuk mendanai kegiatan yang bertujuan meningkatkan kapasitas warga atau masyarakat Desa dalam pengembangan wirausaha, peningkatan pendapatan, serta perluasan skala ekonomi individu warga atau kelompok masyarakat dan Desa,

3. Memberikan pelayanan dan dukungan pemberdayaan untuk kaum miskin bukan dalam bentuk santunan cumacuma, tetapi dengan pola dana bergulir.

4. Dana Desa diutamakan untuk membiayai kepentingan Desa dan masyarakat Desa, bukan kepentingan orang per orang.

5. Dana Desa diutamakan untuk membangun sarana dan prasana dasar (infrastruktur) untuk keperluan mendukung transportasi, irigasi dan sanitasi, pelayanan dasar, ketahanan pangan, energi dan pengembangan ekonomi.

6. Dana Desa diutamakan untuk mengembangkan potensi dan aset budaya dan ekonomi Desa. 
Kegiatan pembangunan Desa yang boleh didanai Dana Desa adalah 1) Sarpras transportasi seperti jalan lingkungan, jalan kampung, jalan poros Desa, jembatan kecil, gorong-gorong, tambatan perahu; 2) Sarpras ekonomi seperti pasar Desa, pasar bersama antarDesa, pasar online, dan sebagainya; 3) Sarpras pendukung ketahanan pangan: embung Desa, saluran irigasi, kolam budidaya ikan darat, bagan atau karamba ikan di pantai, kandang terpadu, jalan usaha tani, dan sebagainya; 4) Sarpras pelayanan dasar: penyediaan air bersih, polindes, poskedes; 5) Sarpras untuk lingkungan: sanitasi, MCK, drainase, tempat pembuangan sampah, parit, pengolahan kompos, dan sebagainya; 6) Pengembangan sistem infomasi Desa dan peta sosial digital; 7) Pengembangan teknologi tepat guna; 8) Pengembangan energi lokal yang terbarukan; 9) Pengembangan dan penyertaan modal untuk Badan Usaha Milik Desa (BUMDesa) maupun BUMADesa; 10) Gerakan Desa menanam: sayur, buah, benih, palawija, hortikultura, tanaman keras dan sebagainya; 11) Pengembangan seni dan budaya Desa; 12) Penyelenggaraan PAUD dan Posyandu; 13) Perpustakaan Desa dan sanggar belajar; 14) Pengembangan budidaya obat tradisional; dan 15) Dan lain sebagainya.

Kegiatan pemberdayaan masyarakat apa yang boleh dibiayai dari Dana Desa diantaranya adalah untuk 1) Pengembangan atau bantuan alat-alat produksi maupun permodalan kepada pelaku ekonomi Desa dengan pola bergulir; 2) Peningkatan kapasitas melalui pelatihan dan pemagangan bagi pengurus BUMDesa maupun pelaku ekonomi Desa; 3) Peningkatan kapasitas untuk program dan kegiatan ketahanan pangan Desa; 4) Pengorganisasian masyarakat, fasilitasi dan pelatihan paralegal dan bantuan hukum masyarakat Desa, termasuk pembentukan Kader Pemberdayaan Masyarakat Desa (KPMD) dan pengembangan kapasitas Ruang Belajar Masyarakat di Desa (Community Centre); 5) Promosi dan edukasi kesehatan masyarakat serta gerakan hidup bersih dan sehat, termasuk peningkatan kapasitas pengelolaan Posyandu, Poskesdes, Polindes dan ketersediaan atau keberfungsian tenaga medis/swamedikasi Desa; 5) Dukungan terhadap kegiatan pengelolaan Hutan/Pantai Desa dan Hutan/Pantai Kemasyarakatan; 6) Peningkatan kapasitas kelompok masyarakat untuk energi terbarukan dan pelestarian lingkungan hidup; misalnya pelatihan dan pengembangan biofuel, kompos dan lain-lain; dan 7) Peningkatan kapasitas kelompok masyarakat untuk pemanfaatan teknologi tepat guna.

Dana Desa tidak boleh dipergunakan untuk 1) Pembangunan atau perbaikan kantor Desa atau balai Desa; 2) Operasional pemerintah Desa, termasuk pengadaan sarana prasarana kantor Desa (komputer dan alat tulis kantor); 3) Biaya perjalanan dinas Pemerintah Desa dan BPD; 4) Biaya penyelenggaraan pemilihan Kepala Desa; 5) SILTAP, gaji, tunjangan maupun honorarium pemerintah Desa dan BPD serta insentif bagi lembaga kemasyarakatan dan lembaga adat; 6) Kegiatan pembangunan yang menjadi kewenangan Pemerintah Kabupaten/Kota dan/atau Pemerintah, misalnya membangun jalan kabupaten, gedung sekolah (SD, SMP, SMA, SMK); 7) Pembayaran premi BPJS dan BPJK Aparatur Desa; 8) Pembelian lahan untuk kantor Desa; 9) Pengadaan tanah dan sekaligus pembangunan rumah ibadah; 10) Biaya kegiatan keagamaan; 11) Beasiswa sekolah/kuliah bagi aparatur Desa; dan 12) Honor untuk pegawai atau pejabat Kecamatan, Kabupaten/Kota, Provinsi dan Pemerintah.

\section{Tujuan dan Manfaat Penelitian}

Penelitian ini untuk mengidentifikasi permasalahan yang sebenarnya yang ada seputar pengelolaan dan penggunaan dana desa di tingkat desa dan kabupaten di beberapa kabupaten di Sulawesi Utara yang hingga saat ini belum menjadi perhatian khusus. Identifikasi yang dilakukan didasarkan pada Peraturan Pemerintah dan Permendes yang merupakan perwujudan Undang-Undang Nomor 6 tahun 2014.

\section{METODE PENELITIAN}

Penelitian ini mengambil lokasi di Minahasa, Minahasa Utara dan Minahasa Selatan yang merupakan 3 kabupaten terdekat dengan kota Manado sebagai ibukota Provinsi Sulawesi Utara dengan total desa dengan total desa berjumlah 227, 125 dan 157 desa. Metode sampling yang digunakan adalah metode Yamane (1967), yaitu

$$
n=\frac{N}{1+N e^{2}}
$$

dimana $n$ adalah jumlah sample, $N$ adalah jumlah populasi, $e$ adalah precision level yang dalam hal ini menggunakan 0,25. Jumlah sample yang dibutuhkan adalah 509/32.18 = 15,51 dibulatkan menjadi 15 desa. Tingginya jumlah precision level disebabkan oleh kurangnya keinginan dari perangkat desa untuk berpartisipasi dalam pemberian informasi yang dibutuhkan. Jumlah desa desa yang dipilih untuk masing-masing kabupaten adalah 9 desa di Minahasa, 4 desa di Minahasa Utara, dan 2 desa di Minahasa Selatan. Di tiap desa, responden dipilih 
berdasarkan kesiapan dan keinginan perangkat desa untuk menjawab pertanyaan kuesioner yang diberikan baik lewat self-administered atau wawancara. Sehingga setiap desa memiliki jumlah responden yang berbeda-beda. Secara umum, tiap kabupaten memiliki jumlah 12 responden untuk Minahasa, 6 responden untuk Minahasa Utara dan 4 responden untuk Minahasa Selatan, dengan total 22 responden.

Penelitian ini menggunakan pendekatan induktif. Analisa induktif didasarkan pada data (Schadewitz dan Jachna, 2007). Penelitian ini akan menginvestigasi, mengidentifikasi dan memvalidasi masalah-masalah yang sedang dan berpeluang mengganggu efektivitas program Dana Desa dalam mewujudkan semua harapan dari program tersebut. Dalam hal ini, penelitian ini akan menggunakan beberapa metode di antaranya dengan menggunakan instrumen Dimensi Pengukuran Pengelolaan Dana Desa (DP2D2) yang dirancang dalam penelitian ini, sample statistics seperti mean, standard deviation, dan beberapa metode lainnya sesuai kebutuhan pada saat observasi dimulai dengan menggunakan data yang tersedia. Dengan menggunakan metode-metode di atas, penelitian ini dapat menggolongkan desa dan kabupaten mana yang menurut skor yang dibuat untuk DP2D2.

HASIL DAN LUARAN YANG DICAPAI

Studi ini mengidentifikasi pengelolaan dan penggunaan dana desa dengan menggunakan instrumen dimensi pengukuran pengelolaan dana desa (DP2D2). Desa yang diteliti didaftar pada tabel 5.1 di bawah ini.

Tabel 1 Daftar Desa

\begin{tabular}{ccc}
\hline No. & Desa & Kabupaten \\
\hline $\mathbf{1}$ & Tumaluntung & Minahasa Utara \\
$\mathbf{2}$ & Kaasar & Minahasa Utara \\
$\mathbf{3}$ & Kolongan Tetempangan & Minahasa Utara \\
$\mathbf{4}$ & Watutumou Dua & Minahasa Utara \\
$\mathbf{5}$ & Matani Satu & Minahasa Selatan \\
$\mathbf{6}$ & Matani & Minahasa Selatan \\
$\mathbf{7}$ & Raringis & Minahasa \\
$\mathbf{8}$ & Raringis Selatan & Minahasa \\
$\mathbf{9}$ & Tolok & Minahasa \\
$\mathbf{1 0}$ & Liba & Minahasa \\
$\mathbf{1 1}$ & Sendangan & Minahasa \\
$\mathbf{1 2}$ & Pulutan & Minahasa \\
$\mathbf{1 3}$ & Warembungan & Minahasa \\
$\mathbf{1 4}$ & Pineleng Satu & Minahasa \\
$\mathbf{1 5}$ & Pineleng Dua & Minahasa \\
\hline
\end{tabular}

Dari setiap desa, diambil 1 sampai 2 responden. Responden yang dipilih adalah perangkat desa yaitu kepala desa (hukum tua), sekretaris desa, dan kepala urusan keuangan. Pemilihan ini dilakukan karena perangkat desa sangat mengetahui seputaran dana desa yang mereka terima untuk membangun desa mereka. Total responden yang dipilih adalah 22 orang.

Penelitian ini menggunakan 4 dimensi untuk menggambarkan keadaan penggunaan Dana Desa. 3 diantaranya bersifat positif, dimana lebih banyak skor yang di dapat dalam ketiga dimensi ini akan menggambarkan penggunaan dana desa yang lebih merata untuk program yang dianjurkan dan sesuai dengan aturan dan ketentuan pengelolaan yang diberikan dalam Peraturan Menteri Desa no 22 tahun 2016. Dimensi yang pertama adalah Dimensi Pengelolaan Keuangan. Penggunaan Dana Desa untuk kepentingan desa dan masyarakat, proporsi yang tepat dalam pembagian dana untuk Pembangunan Sarana Prasarana Desa dan Pemberdayaan Masyarakat, serta proporsi alokasi dana untuk beberapa program unggulan dalam kegiatan pemberdayaan masyarakat menjadi hal yang dinilai dalam dimensi ini. Dimensi yang kedua adalah Dimensi Pembangunan Sarana Prasarana Desa dimana yang dinilai adalah jumlah projek untuk Sarana Prasarana Desa yang menjadi prioritas sesuai dengan Permendes no 22 tahun 2016. Dimensi Pemberdayaan Masyarkat Desa adalah dimensi ketiga yang dinilai. Sementara Dimensi Penyelewengan merupakan dimensi yang memiliki penilaian yang bersifat negatif, dimana lebih banyak skor yang di dapat pada dimensi ini menandakan adanya penggunaan Dana Desa yang tidak sesuai dengan aturan dan 
ketentuan yang ada. Dimensi ini dinilai berdasarkan komponen yang dibuat dalam bentuk pertanyaan sebagai berikut.

\title{
Tabel 2 Dimensi Penilaian
}

\author{
A. Dimensi Pengelolaan Keuangan \\ $(\max$ skor $=24, \min$ skor $=6$, max rata-rata $=4$, min rata-rata $=1)$
}

\begin{tabular}{|c|c|c|c|}
\hline $\begin{array}{l}\text { Ko } \\
\text { de }\end{array}$ & Pertanyaan & Pilihan Jawaban & $\begin{array}{c}\text { Skor untuk } \\
\text { Jawaban }\end{array}$ \\
\hline A1 & $\begin{array}{l}\text { Jumlah proporsi Dana Desa untuk membiayai kepentingan } \\
\text { Desa Anda dan masyarakatnya (bukan kepentingan pribadi) } \\
\text { adalah: }\end{array}$ & $\begin{array}{l}>95 \%(4), 90-95 \%(3), 85- \\
89 \%(2),<85 \%(1)^{*}\end{array}$ & $4,3,2,1$ \\
\hline A2 & $\begin{array}{l}\text { Jumlah proporsi Dana Desa untuk pembangunan Desa (seperti } \\
\text { sarana dan prasana dasar atau infrastruktur) dalam mendukung } \\
\text { transportasi, irigasi dan sanitasi, pelayanan dasar, ketahanan } \\
\text { pangan, energi dan pengembangan ekonomi adalah: }\end{array}$ & $\begin{array}{c}61-70 \%, 51-60 \%, 41-50 \%,< \\
41 \%\end{array}$ & $4,3,2,1$ \\
\hline $\mathbf{A 3}$ & $\begin{array}{l}\text { Jumlah proporsi Dana Desa untuk pemberdayaan masyarakat } \\
\text { adalah: }\end{array}$ & $\begin{array}{c}31-40 \%, 21-30 \%, 11-20 \% \\
<11 \%\end{array}$ & $4,3,2,1$ \\
\hline A4 & $\begin{array}{l}\text { Dari total Dana Desa untuk pemberdayaan masyarakat, jumlah } \\
\text { proporsi bagi kegiatan peningkatan kapasitas masyarakat Desa } \\
\text { dalam berwirausaha, peningkatan pendapatan, atau perluasan } \\
\text { skala ekonomi masyarakat Desa adalah: }\end{array}$ & $\begin{array}{c}41-50 \%, 31-40 \%, 21-30 \% \\
<21 \%\end{array}$ & $4,3,2,1$ \\
\hline A5 & $\begin{array}{l}\text { Dari total Dana Desa untuk pemberdayaan masyarakat, jumlah } \\
\text { proporsi bagi kegiatan pelayanan dan pemberdayaan kaum } \\
\text { miskin dengan pola dana bergulir adalah: }\end{array}$ & $\begin{array}{c}51-60 \%, 41-50 \%, 31-40 \% \\
<31 \%\end{array}$ & $4,3,2,1$ \\
\hline A6 & $\begin{array}{l}\text { Dari total Dana Desa untuk pemberdayaan masyarakat, jumlah } \\
\text { proporsi bagi kegiatan pengembangan potensi dan aset budaya } \\
\text { untuk menghasilkan nilai ekonomi Desa adalah: }\end{array}$ & $\begin{array}{c}1-5 \%, 6-10 \%, 11-15 \% \text {, di atas } \\
15 \% \text { atau } 0 \%\end{array}$ & $4,3,2,1$ \\
\hline
\end{tabular}

B. Dimensi Pembangunan Sarana Prasarana Desa

$(\max$ skor $=38$, min skor $=11$, max rata-rata $=3,45$, min rata-rata $=1)$

\begin{tabular}{|c|c|c|c|}
\hline $\begin{array}{l}\text { Ko } \\
\text { de }\end{array}$ & Pertanyaan & Pilihan Jawaban & $\begin{array}{c}\text { Skor untuk } \\
\text { Jawaban }\end{array}$ \\
\hline B1 & $\begin{array}{l}\text { Dana Desa untuk mendanai pembangunan Sarpras } \\
\text { Transportasi seperti jalan lingkungan, jalan kampung, jalan } \\
\text { poros Desa, jembatan kecil, gorong-gorong, tambatan perahu }\end{array}$ & $\begin{array}{l}\text { Terdapat minimal } 5 \text { jenis/jumlah } \\
\text { yang didanai, Terdapat } 3-4 \\
\text { jenis/jumlah yang didanai, } \\
\text { terdapat } 1-2 \text { jenis/jumlah yang }\end{array}$ & $4,3,2,1$ \\
\hline
\end{tabular}

B2 Dana Desa untuk mendanai pembangunan Sarpras Ekonomi seperti pasar Desa, pasar bersama antarDesa, pasar online, dan sebagainya.

Terdapat minimal 3 jenis/jumlah
yang didanai, Terdapat 2
jenis/jumlah yang didanai,
Terdapat minimal 1 jenis/jumlah
yang didanai, Tidak ada yang
didanai.
Terdapat minimal 5-6
jenis/jumlah yang
didanai,Terdapat 3-4
jenis/jumlah yang didanai,
Terdapat 1-2 jenis/jumlah yang
didanai, Tidak ada yang didanai.
Terdapat minimal 7-9
jenis/jumlah Sarpras yang
didanai, Terdapat 4-6
jenis/jumlah Sarpras yang
didanai, Terdapat 1-3
jenis/jumlah Sarpras yang
didanai, Tidak terdapat salah
satu jenis/jumlah Sarpras yang
didanai.
Terdapat minimal 3 jenis/jumlah
Sarpras yang didanai, Terdapat
2 jenis/jumlah Sarpras yang
didanai, Terdapat 1 jenis/jumlah
Sarpras yang didanai, Tidak ada
yang didanai.




\begin{tabular}{|c|c|c|c|}
\hline B6 & $\begin{array}{l}\text { Dana Desa untuk mendanai pembangunan Sarpras } \\
\text { Pengembangan dan Penyertaan Modal untuk Badan Usaha } \\
\text { Milik Desa (BUMDesa) maupun BUMADesa. }\end{array}$ & $\begin{array}{l}\text { Ada yang didanai, Tidak ada } \\
\text { yang didanai. }\end{array}$ & 3,1 \\
\hline B7 & $\begin{array}{l}\text { Dana Desa untuk mendanai pembangunan Sarpras } \\
\text { Penyelenggaraan PAUD dan Posyandu. }\end{array}$ & $\begin{array}{l}\text { Ada yang didanai, Tidak ada } \\
\text { yang didanai. }\end{array}$ & 3,1 \\
\hline B8 & $\begin{array}{l}\text { Dana Desa untuk mendanai pembangunan Sarpras } \\
\text { Perpustakaan Desa dan Sanggar Belajar. }\end{array}$ & $\begin{array}{l}\text { Ada yang didanai, Tidak ada } \\
\text { yang didanai. }\end{array}$ & 3,1 \\
\hline B9 & $\begin{array}{l}\text { Dana Desa untuk mendanai pembangunan Sarpras } \\
\text { Pengembangan Seni dan Budaya Desa. }\end{array}$ & $\begin{array}{l}\text { Ada yang didanai, Tidak ada } \\
\text { yang didanai. }\end{array}$ & 3,1 \\
\hline B10 & $\begin{array}{l}\text { Dana Desa untuk mendanai pembangunan Sarpras Gerakan } \\
\text { Desa Menanam: sayur, buah, benih, palawija, hortikultura, } \\
\text { tanaman keras dan sebagainya. }\end{array}$ & $\begin{array}{l}\text { Ada yang didanai, Tidak ada } \\
\text { yang didanai. }\end{array}$ & 3,1 \\
\hline B11 & $\begin{array}{l}\text { Dana Desa untuk mendanai pembangunan Sarpras } \\
\text { Pengembangan Budidaya Obat Tradisional. }\end{array}$ & $\begin{array}{l}\text { Ada yang didanai, Tidak ada } \\
\text { yang didanai. }\end{array}$ & 3,1 \\
\hline \multicolumn{4}{|c|}{$\begin{array}{c}\text { C. Dimensi Pembangunan Sarana Prasarana Desa } \\
(\max \text { skor }=32, \text { min skor }=8, \text { max rata-rata }=4, \text { min rata-rata }=1)\end{array}$} \\
\hline $\begin{array}{c}\text { Kod } \\
\text { e }\end{array}$ & Pertanyaan & Pilihan Jawaban & $\begin{array}{l}\text { Skor untuk } \\
\text { Jawaban }\end{array}$ \\
\hline
\end{tabular}

C1 Dana Desa untuk pengembangan atau bantuan alat-alat produksi maupun permodalan kepada pelaku ekonomi Desa dengan pola bergulir.

C2 Dana Desa untuk peningkatan kapasitas melalui pelatihan dan magang bagi pengurus BUMDesa maupun pelaku ekonomi Desa.

C3 Dana Desa untuk peningkatan kapasitas untuk program dan kegiatan ketahanan pangan Desa.
Ya dengan dokumen yang lengkap, Ya namun dokumen pendukung kurang lengkap, Ya namun dokumen tidak lengkap, Tidak

Ya dengan dokumen yang lengkap, Ya namun dokumen pendukung kurang lengkap, Ya namun dokumen tidak lengkap, Tidak

Ya dengan dokumen yang lengkap, Ya namun dokumen pendukung kurang lengkap, Ya namun dokumen tidak lengkap, Tidak

Ya dengan dokumen yang lengkap, Ya namun dokumen pendukung kurang lengkap, Ya namun dokumen tidak lengkap, Tidak

Ya dengan dokumen yang lengkap, Ya namun dokumen pendukung kurang lengkap, Ya namun dokumen tidak lengkap, Tidak

Ya dengan dokumen yang

$4,3,2,1$ pelatihan paralegal dan bantuan hukum masyarakat Desa, termasuk pembentukan Kader Pemberdayaan Masyarakat Masyarakat di Desa(Community Centre).

C5 Dana Desa untuk promosi dan edukasi kesehatan masyarakat serta gerakan hidup bersih dan sehat, termasuk peningkatan kapasitas pengelolaan Posyandu, Poskesdes, Polindes dan ketersediaan atau keberfungsian tenaga medis/swamedikasi Desa.

C6 Dana Desa untuk dukungan terhadap kegiatan pengelolaan Hutan/Pantai Desadan Hutan/Pantai Kemasyarakatan.

C7 Dana Desa untuk peningkatan kapasitas kelompok masyarakat untuk energi terbarukan dan pelestarian lingkungan hidup; misalnya pelatihan dan pengembangan biofuel, kompos dan lain-lain.

C8 Dana Desa untuk peningkatan kapasitas kelompok masyarakat untuk pemanfaatan teknologi tepat guna. lengkap, Ya namun dokumen

pendukung kurang lengkap, Ya namun dokumen tidak lengkap,

Tidak

Ya dengan dokumen yang

lengkap, Ya namun dokumen pendukung kurang lengkap, Ya namun dokumen tidak lengkap, Tidak

Ya dengan dokumen yang

$4,3,2,1$ pendukung kurang lengkap, $\mathrm{Ya}$ namun dokumen tidak lengkap, Tidak 


\begin{tabular}{|c|c|c|c|}
\hline $\begin{array}{c}\text { Kod } \\
\text { e }\end{array}$ & Pertanyaan & Pilihan Jawaban & $\begin{array}{l}\text { Skor untuk } \\
\text { Jawaban }\end{array}$ \\
\hline D1 & $\begin{array}{l}\text { Dana Desa dipergunakan untuk membantu pembangunan atau } \\
\text { perbaikan kantor Desa atau balai Desa. }\end{array}$ & YA, TIDAK & 4,1 \\
\hline D2 & $\begin{array}{l}\text { Dana Desa dipergunakan untuk membantu operasional } \\
\text { pemerintah Desa, termasuk pengadaan sarana prasarana } \\
\text { kantor Desa (komputer dan alat tulis kantor). }\end{array}$ & YA, TIDAK & 4,1 \\
\hline D3 & $\begin{array}{l}\text { Dana Desa dipergunakan untuk membantu membiayai } \\
\text { perjalanan dinas Pemerintah Desa dan BPD. }\end{array}$ & YA, TIDAK & 4,1 \\
\hline D4 & $\begin{array}{l}\text { Dana Desa dipergunakan untuk membantu membiayai } \\
\text { penyelenggaraan pemilihan Kepala Desa. }\end{array}$ & YA, TIDAK & 4,1 \\
\hline D5 & $\begin{array}{l}\text { Dana Desa dipergunakan untuk membantu membiayai } \\
\text { SILTAP, gaji, tunjangan maupun honorarium pemerintah } \\
\text { Desa dan BPD serta insentif bagi lembaga kemasyarakatan } \\
\text { dan lembaga adat. }\end{array}$ & YA, TIDAK & 4,1 \\
\hline D6 & $\begin{array}{l}\text { Dana Desa dipergunakan untuk membantu pembangunan } \\
\text { yang jalan kabupaten, gedung sekolah (SD, SMP, SMA, } \\
\text { SMK) yang menjadi kewenangan Pemerintah } \\
\text { Kabupaten/Kota. }\end{array}$ & YA, TIDAK & 4,1 \\
\hline D7 & $\begin{array}{l}\text { Dana Desa dipergunakan untuk membantu pembayaran premi } \\
\text { BPJS dan BPJK Aparatur Desa. }\end{array}$ & YA, TIDAK & 4,1 \\
\hline D8 & $\begin{array}{l}\text { Dana Desa dipergunakan untuk membantu pembelian lahan } \\
\text { untuk kantor Desa. }\end{array}$ & YA, TIDAK & 4,1 \\
\hline D9 & $\begin{array}{l}\text { Dana Desa dipergunakan untuk membantu pengadaan tanah } \\
\text { dan sekaligus pembangunan rumah ibadah. }\end{array}$ & YA, TIDAK & 4,1 \\
\hline D10 & $\begin{array}{l}\text { Dana Desa dipergunakan untuk membantu membiayai } \\
\text { kegiatan keagamaan. }\end{array}$ & YA, TIDAK & 4,1 \\
\hline D11 & $\begin{array}{l}\text { Dana Desa dipergunakan untuk beasiswa sekolah/kuliah bagi } \\
\text { aparatur Desa. }\end{array}$ & YA, TIDAK & 4,1 \\
\hline D12 & $\begin{array}{l}\text { Dana Desa dipergunakan untuk membantu membiayai honor } \\
\text { untuk pegawai atau pejabat Kecamatan, Kabupaten/Kota, } \\
\text { Provinsi dan Pemerintah. }\end{array}$ & YA, TIDAK & 4,1 \\
\hline
\end{tabular}

*) Angka dalam kurung menunjukkan skor untuk pilihan jawaban tertentu. Baris pilihan jawaban ini merupakan contoh pemberian skor yang juga berlaku untuk semua pilihan jawaban yang lain. Sumber: Desain Kuesioner Penulis

Kabupaten Minahasa Utara mendapat skor 2,53 untuk Dimensi Pengelolaan Keuangan dari 4 poin yang bisa diperoleh. Dalam penilaian penggunaan Dana Desa untuk kepentingan masyarakat dan bukan pribadi, serta pembagian prioritas diantara Pembangunan Sarana Prasarana Desa dan Pemberdayaan Masyarakat Desa dengan ratio $70 \%$ dan 30\%, desa-desa di Minahasa Utara mencatatkan nilai yang baik. Dari 4 desa yang ada, semua desa mendapatkan skor 3 dan 4 untuk ketiga pengukuran ini. Namun hal yang berbeda justru terjadi dalam pengukuran alokasi dana yang diberikan untuk beberapa program prioritas yang termasuk dalam Program Pemberdayaan Masyarakat yaitu untuk Kegiatan Peningkatan Kapasitas Masyarakat Desa, Kegiatan Pelayanan dan Pemberdayaan Kaum Miskin, dan Kegiatan Pengembangan Potensi Aset dan Budaya Desa. Dalam ketiga pengukuran ini desa-desa di Minahasa Utara mendapat skor 1 dan 2, hanya 1 desa yang memiliki skor 3 untuk alokasi dana dalam salah satu kegiatan yang dinilai. Dalam Dimensi Pembangunan Sarana dan Prasarana Desa, Kabupaten Minahasa Utara mencatatkan skor rata-rata 1,79 dari 3,45 poin yang dapat diperoleh. 
(a)

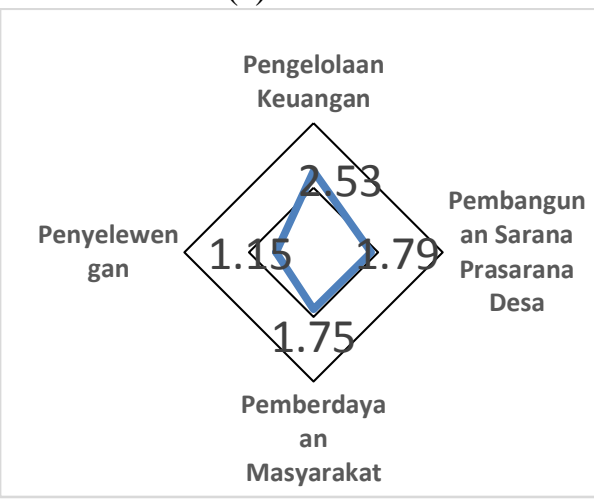

(b)

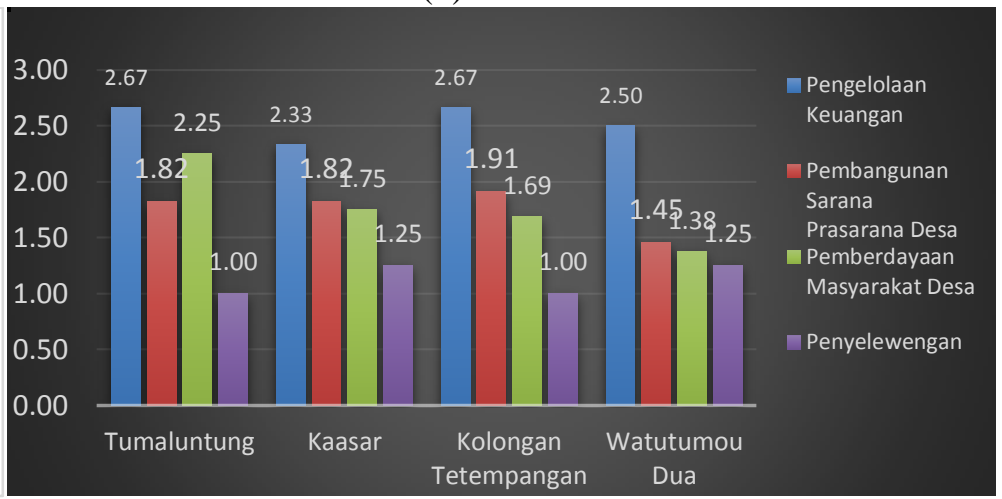

Gambar 1. Pemetaan Skor Rata-Rata Desa di Minahasa Utara (a) dan Skor Masing-masing Desa di Minahasa Utara (b) Sumber: Olahan Data Penulis

Pada Dimensi Pembangunan Sarana Prasarana Desa, desa-desa di Minahasa Utara cenderung terfokus pada pembangunan jenis sarpras tertentu. Dalam hal ini sarpras yang dimaksud adalah Sarpras Transportasi, Sarpras Pelayanan Dasar, serta untuk Pembiayaan dan Permodalan BUMDesa atau BUMADesa. 3 dari 4 desa yang ada mencatatkan skor 4 dalam pengukuran Sarpras Transportasi yang didanai, untuk Sarpras Posyandu dan PAUD 3 desa mencatatkan skor 3, dan 3 desa juga telah melaksanakan pendanaan untuk BUMDesa atau BUMADesa. Untuk Dimensi Pemberdayaan Masyarakat Desa di Kabupaten Minahasa Utara lebih bervariasi dan tidak terkonsentrasi sama halnya pada Dimensi Pembangunan Sarana Prasarana. Desa Watutumou Dua hanya membiayai satu program Pemberdayaan Masyarakat Desa, Desa Kolongan Tetempangan dan Kaasar 3 program dan yang terbanyak Desa Tumaluntung dengan 5 program. Namun kelengkapan dokumen untuk kegiatan tersebut masih harus diperbaiki karena hampir semua program yang diadakan tersebut tidak disertai dengan bukti dokumen yang lengkap. Dari semua kegiatan yang didukung, ada dua kegiatan prioritas dalam Dimensi Pemberdayaan Masyarkat yang tidak didanai oleh keempat desa tersebut yaitu Kegiatan Peningkatan Kapasitas Masyarakat untuk Energi Terbarukan dan Kegiatan Pengelolaan Hutan dan Pantai Desa atau Masyarakat, yang dikarenakan desa-desa tersebut tidak memiliki hutan dan berada di daerah pantai. Dimensi penyelewengan sebagai dimensi yang terakhir berada pada posisi 1,15. Desa Tumaluntung dan Kolongan Tetempangan mencatatkan skor 1 atau tidak menggunakan Dana Desa untuk pembiayaan atau pembangunan yang tidak menjadi prioritas atau tidak sesuai dengan aturan yang ada. Desa Kaasar tercatat menggunakan Dana Desa untuk membantu perbaikan kantor desa atau balai desa dan untuk membantu operasional pemerintah desa, sedangkan Desa Watutumou mennggukan dana desa untuk membantu operasional pemerintah desa.

Desa Kaasar mencatatkan nilai terendah pada Dimensi Pengelolaan Keuangan dengan skor 2,33. Desa Kaasar memiliki proporsi alokasi Dana Desa yang kecil untuk 3 program prioritas Pemberdayaan Masyarkat yaitu Peningkatan Kapasitas Masyarakat Desa, Pelayanan dan Pemberdayaan Kaum Miskin dan Pengembangan Potensi dan Aset Budaya Desa yang terdapat pada poin A4, A5, dan A6. Dalam hal Pembangunan Sarana Prasarana Desa, dari 11 poin yang dinilai, hanya 4 program pembangunan sarpras prioritas yang tidak diadakan oleh Desa Kaasar sedangkan 7 lainnya telah sementara ataupun sudah selesai diadakan. Dengan 7 program yang didanai, Desa Kaasar mencatatkan skor 1,82 pada Dimensi Pembangunan Sarana Prasarana Desa. Hal yang berbeda justru terjadi pada Dimensi Pemberdayaan Masyarakat, dimana Desa Kaasar dengan menggunakan Dana Desa hanya mendanai 3 program prioritas dari total 8 program prioritas yang diukur pendanaannya. Program Pelatihan dan Magang Pengurus BUMDes dan Pelaku Ekonomi Desa didanai dengan ketersediaan dokumen yang lengkap, sedangkan 2 program lainnya yang diadakan lewat Dana Desa tidak memiliki ketersediaan dokumen yang lengkap. Pada Dimensi Penyelewengan terdapat 2 program yang diadakan yang tidak sesuai dengan program prioritas dan aturan Dana Desa yaitu untuk membantu pembangunan dan perbaikan balai desa serta membantu membiayai operasional pemerintah desa.

Desa Watutumou Dua memiliki karakteristik yang sama dengan Desa Kaasar pada Dimensi Pengelolaan Keuangan dimana desa ini juga memiliki proporsi alokasi dana yang rendah untuk 3 kegiatan pemberdayaan 
masyarakat yang termasuk dalam prioritas Dana Desa. Desa Watutumou Dua mencatatkan nilai 1 pada ketiga jenis kegiatan yang ada pada poin A4, A5, dan A6. Pembangunan Sarana Prasarana di desa ini hanya terfokus pada Sarpras Transportasi dan Penyelenggaraan PAUD dan Posyandu serta tidak ada pengadaan sarpras lainnya yang dialokasikan lewat Dana Desa. Hal ini membuat skor pada Dimensi Pembangunan Sarana Prasarana Desa berada pada posisi yang rendah, 1,45. Skor untuk Dimensi Pemberdayaan Masyarkat juga berada dibawah dengan nilai 1,38, hal ini dikarenakan Desa Watutumou Dua hanya mendanai 1 program yaitu Promosi dan Edukasi Kesehatan Masyarakat serta Gerakan Hidup Bersih dan Sehat. Pada Dimensi Penyelewengan ada satu program yang bukan menjadi prioritas ataupun sesuai dengan aturan yang didanai yaitu pembiayaan operasional pemerintah desa.

Tumaluntung dan Kolongan Tetempangan merupakan desa-desa dengan skor tertinggi pada Dimensi Pengelolaan Keuangan di Kabupaten Minahasa Utara. Kedua desa ini mencatatkan skor 2,67. Pada poin penilaian A1, A2, dan A3, kedua desa ini mecatatkan nilai yang baik, dan kedua desa ini juga mengalokasikan dana dengan proporsi yang cukup untuk Kegiatan Peningkatan Kapasitas Masyarakat Desa yang diambil dari dana untuk Pemberdayaan Masyarakat. Sedangkan untuk Dimensi Pembangunan Sarana Prasaran Desa, skor Desa Kolongan Tetempangan sedikit lebih diatas dari Desa Tumaluntung yaitu masing-masing dengan nilai 1,91 dan 1,82. Desa Tumaluntung membiayai 3 jenis pembangunan sarpras dari 11 jenis sarpras prioritas yang dinilai sedangkan Desa Kolongan Tetempangan mengadakan 7 jenis pembangunan sarpras yang berbeda. Pada Dimensi Penyelewengan tidak ada pendanaan bukan program prioritas dan yang tidak sesuai dengan ketentuan yang dilakukan oleh kedua desa ini sehingga pada dimensi keempat keduanya mencatatkan skor 1.

Berbeda dengan Kabupaten Minahasa Selatan, Grafik 2 menunjukkan bahwa Kabupaten Minahasa Selatan memiliki nilai 0,01 lebih tinggi pada Dimensi Pengelolaan Keuangan dari Kabupaten Minahasa Utara yaitu 2,54. Desa-desa di Kabupaten Minahasa Selatan mencatatkan nilai yang baik pada poin pengukuran A1, A2, dan A3. Dalam 3 pengukuran awal ini desa-desa di Minahasa Selatan mencatatkan skor antara 3 dan 4 tetapi alokasi dana untuk program prioritas dalam Pemberdayaan Masyarakat yang ada pada poin A4, A5 dan A6 masih rendah. Sama seperti Kabupaten Minahasa Utara, skor untuk 3 poin penilaian ini berada pada kisaran nilai 1 dan 2. Desa Matani mencatatkan skor yang sangat baik untuk tiga kategori penilaian pertama dengan nilai 4 untuk A1 dan A2 dan nilai 3 untuk A3. Alokasi yang rendah terhadap 3 program prioritas pemberdayaan masyarakat di dimensi yang pertama ini membuat Matani hanya mencatatkan skor 2 pada poin penilaian A4 dan skor 1 pada 2 poin lainnya. Sedangkan Desa Matani Satu mencatatkan skor yang lebih rendah untuk 3 poin penilaian pertama berada di sekitaran nilai 2 dan 4 tetapi lebih baik pada 3 poin penilaian berikutnya daripada Desa Matani untuk penilaian alokasi dana untuk pemberdayaan masyarakat.

(a)

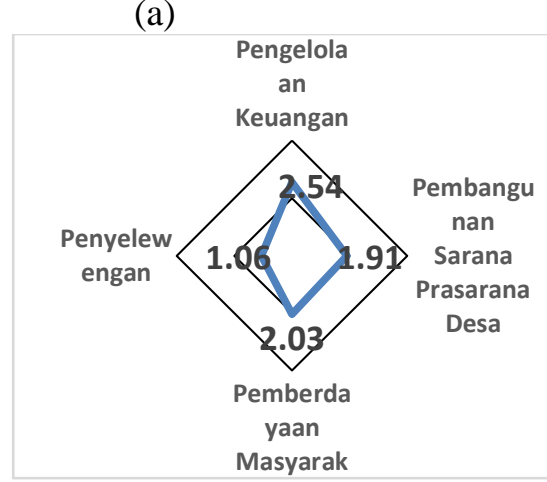

(b)

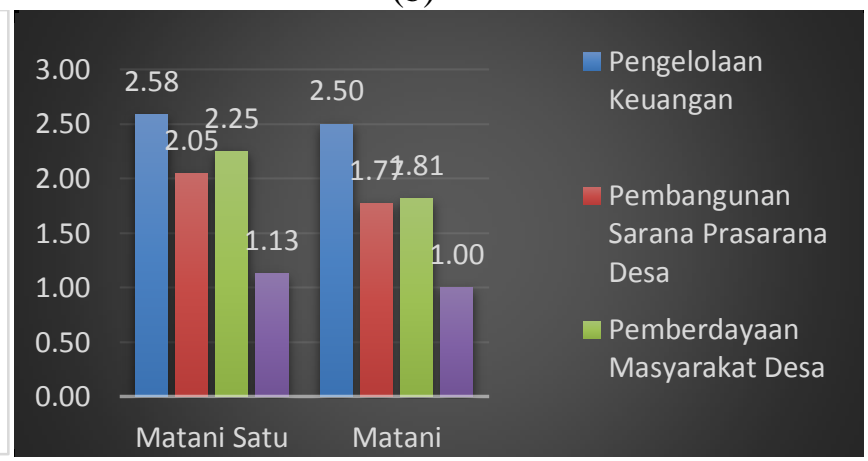

\section{Gambar 2. Pemetaan Skor Rata-Rata Desa di Minahasa Selatan (a) dan Skor Masing-masing Desa di Minahasa Selatan (b) Sumber: Olahan Data Penulis}

Untuk Dimensi Pembangunan Sarana Prasarana, skor Kabupaten Minahasa Selatan adalah 1,91, merupakan yang tertinggi dibandingkan dengan 2 kabupaten lainnya. Hal ini merupakan hasil dari banyaknya jenis sarpras prioritas yang didanai desa-desa di Minahasa Selatan. Desa Matani Satu tercatat mengadakan pembangunan 7 jenis sarpras. Pembangunan sarpras transportasi seperti jalan desa masih menjadi fokus pemerintah desa. Hal ini bisa dilihat dari skor 4 yang di dapat pada poin penilian B1 yang berarti ada 5 atau lebih jumlah sarpras ini yang didanai. Untuk 6 jenis sarpras lain yang didanai, memiliki skor 2 atau 3. Jumlah skor yang didapat Desa Matani Satu untuk 
Dimensi Pembangunan Sarana Prasarana Desa adalah 2,05. Sedangkan skor untuk Desa Matani berada lebih di bawah pada posisi 1,77 .

Pada Dimensi Pemberdayaan Masyarkat, nilai Desa Matani Satu berada diatats Desa Matani. Hal ini dikarenakan pengadaan Program Pemberdayaan Masyarakat lebih banyak di didanai oleh Desa Matani Satu dengan total 6 jenis program. Sedangkan untuk Desa Matani hanya mendanai 4 dari 8 program prioritas yang dinilai. Kelengkapan dokumen untuk program-program tersebut dinilai kurang lengkap. Tercatat hanya 1 program dari tiap desa yang memiliki dokumen yang lengkap. Dari semua desa yang diteliti, Desa Matani merupakan desa dengan jumlah jenis program prioritas Dimensi Pemberdayaan Masyarakat terbanyak yang didanai yaitu dengan jumlah 6 dari total 8 program yang dinilai.

Pada dimensi keempat yang dinilai, terdapat satu program yang tidak sesuai dengan ketentuan penggunaan Dana Desa yang dibiayai oleh Desa Matani Satu. Desa Matani Satu tercatat menggunakan Dana Desa untuk membantu membiayai penyelenggaraan pemilihan kepala desa seperti yang diukur pada poin D4. Selain dari itu, kedua desa di Minahasa Selatan ini tidak menggunakan Dana Desa untuk program yang tidak menjadi prioritas ataupun tidak sesuai dengan aturan yang ada. Hal ini membuat skor Dimensi Penyelewengan di Kabupaten Minahasa Selatan menjadi 1,06, merupakan yang terendah dibandingkan dengan kabupaten lainnya.

Sebagai kabupaten terakhir yang diteliti, Kabupaten Minahasa merupakan kabupaten dengan jumlah sampel desa yang terbanyak. Ada 9 desa dalam sampel berasal dari Kabupaten Minahasa. Grafik 3 menunjukkan bahwa, dmensi Pengelolaan Keuangan Kabupaten Minahasa memiliki skor 2,75, merupakan yang tertinggi dibandingkan dengan kabupaten lainnya. Sedangkan untuk Dimensi Pembangunan Sarana Prasarana Desa, berada sedikit dibawah Kabupaten Minahasa Selatan masing-masing dengan nilai 1,89 dan 1,91. Tetapi untuk Dimensi Pemberdayaan Masyarakat, Kabupaten Minahasa menempati posisi paling bawah dengan skor 1,68. Untuk dimensi yang terakhir, Dimensi Penyelewengan, skor yang diperoleh adalah 1,27.

(a)

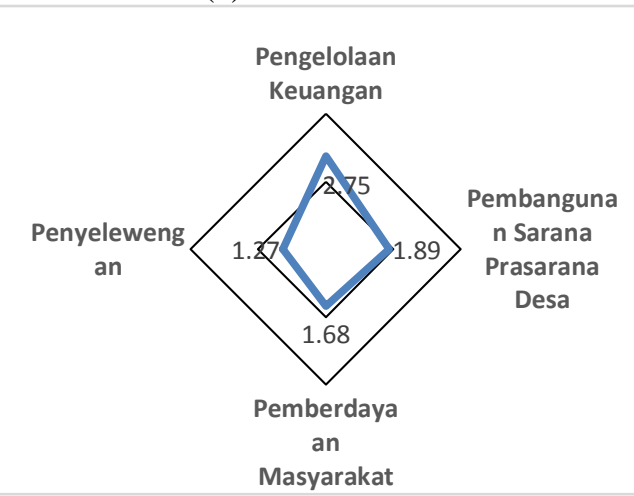

(b)

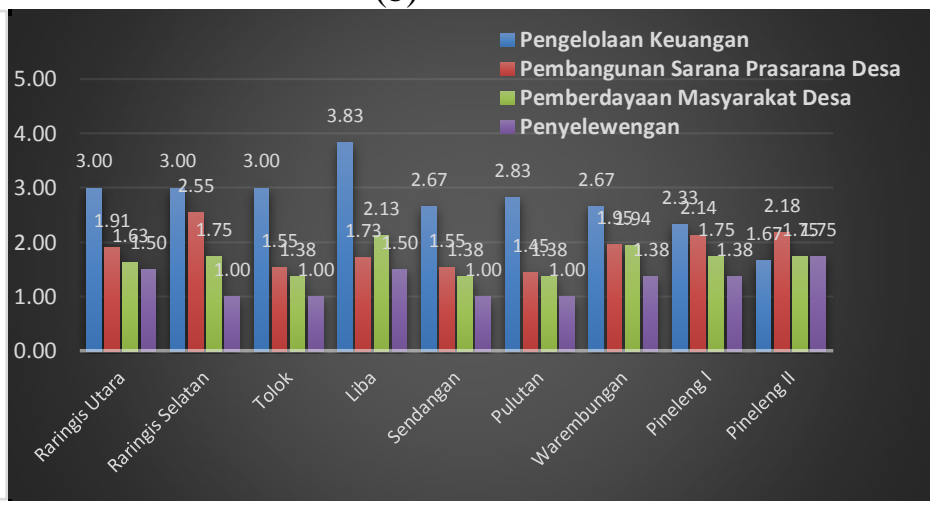

Gambar 3. Pemetaan Skor Rata-Rata Desa di Minahasa (a) dan Skor Masing-masing Desa di Minahasa (b) Sumber: Data Olahan Penulis

Desa-desa di Minahasa jika dilihat dari skor rata-rata untuk Dimensi Pengelolaan Keuangan, dapat dikelompokan menjadi 3 kategori yaitu desa yang memiliki skor diatas 3, antara 2 dan 3 dan desa dengan skor dibawah 2. Desa-desa dengan skor diatas 3 dapat dikatakan telah melaksanakan pengelolaan keuangan untuk Dana Desa dengan baik. Ada 4 desa yang termasuk pada kategori ini yaitu Desa Liba, Raringis Utara, Raringis Selatan dan Tolok. Kategori dengan skor antar 2 dan 3 juga ditempati oleh 4 desa, yaitu Desa Sendangan, Pulutan, Warembungan dan Pinileng I. Desa Pineleng II menajadi satu-satunya desa yang mencatatkan skor dibawah 2 pada Dimensi Pengelolaan Keuangan yaitu 1,67, skor ini juga menjadi yang terendah dari seluruh desa di 3 kabupaten. Pada Dimensi Pembangunan Sarana Prasarana Desa, Desa Raringis Selatan menempati posisi teratas dengan skor tertinggi dari semua desa yang diteliti dengan nilai 2,55. Hal ini terjadi karena desa ini tercatat melaksanakan pembiayaan untuk 8 jenis sarpras yang berbeda. Desa Pineleng I dan Pineleng II juga memiliki skor diatas 2 untuk dimensi kedua ini, 6 desa lainnya mencatatkan skor dibawah 2. Pendanaan yang terfokus pada Sarpras Transportasi dan BUMDesa atau BUMADes merupakan salah satu penyebab skor yang dimiliki 6 desa di Minahasa rendah. 
Selain 2 program tersebut, Program Pembangunan Sarpras Penyelenggaraan PAUD dan Posyandu juga menjadi program yang banyak didanai desa-desa di Minahasa. Pada Dimensi Pemberdayaan Masyarakat, hanya Desa Liba yang memiliki nilai diatas 2, sedangkan 8 desa lainnya memiliki skor yang di bawah 2. Sedikitnya jenis program pemberdayaan masyarakat yang didanai menyebabkan skor rata-rata desa-desa di Minahasa pada dimensi ini rendah.

Yang membuat skor Kabupaten Minahasa pada Dimensi Pengeloalaan Keuangan cukup tinggi adalah skor desa-desa yang baik pada 3 poin penilaian awal. Penggunaan Dana Desa yang sepenuhnya untuk kepentingan masyarakat dan pembagian proporsi 70:30 untuk Program Pembangunan Sarana Prasarana Desa dan Pemberdayaan Masyarakat telah telah diterapkan dengan baik oleh desa-desa tersebut. Dari 9 desa yang ada, 6 desa diantaranya memperoleh nilai 4 pada poin penilian A1, A2, dan A3, kecuali Desa Rarignis Utara yang hanya mencatatkan skor 3 pada poin penilian A3. Hal ini dapat diartikan pengelolaan Dana Desa di 6 desa ini telah sesuai dengan aturan dan ketentuan yang seharusnya. 2 desa lainnya yaitu Pineleng I dan Warembungan mencatatkan skor pada kisaran 2 dan 3 untuk 3 poin penilian pertama. Sedangkan Desa Pineleng II berada pada posisi terendah dengan hanya mencatatkan skor 1, 2, dan 1 untuk 3 poin penilaian tersebut. Pada 3 poin penilaian berikutnya, desa-desa di Minahasa mencatatkan skor yang bervariasi. Desa Liba merupakan desa yang mencatatkan skor tinggi untuk 3 poin penilaian kategori alokasi Dana Desa untuk program-program pemberdayaan masyarakat unggulan. Pada poin A4, A5 dan A6 hanya desa Liba yang memiliki konsistensi skor 3 dan 4 untuk 3 poin penilaian ini.

Jika dinilai dari Dimensi Pembangunan Sarana dan Prasaran Desa, dapat dilihat bahwa desa-desa di Kabupaten Minahasa cenderung lebih fokus mengadakan program pembangunan Sarpras Transportasi seperti jalan desa. Semua desa di Minahasa tercatat mendanai pembangunan Sarpras Transportasi. Kurangnya pendanaan Sarpras Ekonomi dikarenakan kebanyakan desa-desa ini tidak memiliki pasar dan akan menghabiskan biaya yang besar untuk membangun sebuah pasar yang baru. Desa Raringis Utara, Raringis Selatan dan Pineleng II adalah 3 desa yang tercatat memakai Dana Desa untuk membiayai pembangunan Sarpras Ketahanan Pangan. Dalam hal pembangunan Sarpras Pelayanan Dasar pada poin B4, ada 5 desa yang tercatat membiayai program prioritas ini, 6 desa membiayai Sarpras Pengembangan Informasi Desa dan semua desa yang diteliti di Kabupaten Minahasa tercatat telah melaksanakan pembiayaan untuk BUMDesa atau BUMADesa. Bahkan dari semua desa yang ada di 3 kabupaten hanya Desa Watutumou Dua yang tidak mengadakan pembiayaan BUMDes atau BUMADesa. 7 desa di Minahasa juga tercatat mengadakan pembiayaan untuk kegiatan Posyandu atau PAUD hanya desa Raringis Selatan dan Pulutan yang tidak. Pembangunan atau pendanaan Sarpras Perpustakaan Desa atau Sanggar Belajar yang dinilai pada poin B8 juga telah diadakan oleh 5 desa di Minahasa tapi hanya 4 desa yang mendanai pembangunan Sarpras Pengembangan Seni dan Budaya Desa. Desa Raringis Selatan dan Liba adalah dua desa yang mengadakan pembiayaan untuk Sarpras Gerakan Desa Menanam. Meskipun Sarpras Budidaya Obat Tradisional merupakan salah satu sarpras prioritas dalam Permendes, tapi dari semua desa yang diteliti tidak ditemukan ada desa yang mendanai sarpras jenis ini.

Dimensi Pemberdayaan Masyarakat di Kabupaten Minahasa mencatatkan skor terendah bila dibandingkan dengan kabupaten lainnya. Jika diteliti sampai pada tingkat desa, desa-desa di Minahasa tidak banyak melakukan pengadaan program yang masuk dalam Dimensi Pemberdayaan Masyarakat. Program Pengembangan atau Bantuan kepada Pelaku Ekonomi yang ada pada poin C1 dan Program Pengorganisasian Masyarakat, Fasilitasi Paralegal dan Bantuan Hukum pada poin C4, masing-masing hanya dibiayai oleh 1 desa. Desa Pineleng I satu-satunya desa yang telah mengadakan pembiayaan program pada poin $\mathrm{C} 1$ dan dan Desa Warembungan mengadakan pendanaan program yang ada pada poin C4. Satu program yang menjadi fokus desa-desa di Minahasa adalah Program Peningkatan Kapasitas Pengurus BUMDes dan Pelaku Ekonomi Desa yang diadakan oleh 7 dari 9 desa yang ada. 2 desa tercatat membiayai program yang ada pada poin $\mathrm{C} 3$, dan 4 desa membiayai program yang pada poin C5 dan C7. Program Peningkatan Kapasitas Masyarkat melalui Pemanfaatan Teknologi Tepat Guna tidak dibiayai oleh satu desa pun yang ada di Minahasa.

Dengan skor rata-rata 1,27, Dimensi Penyelewengan Kabupaten Minahasa merupakan yang tertinggi dibandingkan 2 kabupaten lainnya. Dari 9 desa yang ada, hanya 4 desa di Minahasa yang tercatat tidak mendanai program bukan prioritas Dana Desa atau yang tidak sesuai dengan ketentuan yang ada. Keempat desa tersebut adalah Desa Raringis Selatan, Desa Tolok, Desa Sendangan dan Desa Pulutan. 5 desa lainnya tercatat melaksanakan pendanaan untuk program bukan prioritas yang terdapat pada poin penilain D3 dan D5. Desa Warembungan dan 
Pineleng I juga tercatat menggunakan Dana Desa untuk membantu kegiatan operasional pemerintah desa dan Desa Pineleng II menggunakan Dana Desa untuk membantu pembiayaan pemilihan Kepala Desa.

\section{Kesimpulan dan Saran}

\section{PENUTUP}

Berdasarkan hasil yang diperoleh, pada dimensi pertama Kabupaten Minahasa memiliki skor tertinggi dengan nilai 2,75, diikuti Kabupaten Minahasa Utara dan Minahasa Selatan dengan skor masing-masing 2,54 dan 2,53. Kebanyakan desa yang diteliliti telah menggunakan Dana Desa untuk mendanai kepentingan masyarakat dan bukan kepentingan pribadi seperti yang dinilai pada poin A1. Kebanyakan desa yang diteliti juga mencatatkan skor 3 dan 4 untuk poin A2 dan A3 yang artinya proporsi Dana Desa yang alokasikan untuk Pembangunan Sarana dan Prasarana Desa dan Pemberdayaan Masyarakat juga telah sesuai dengan peraturan yang menganjurkan rasio sebesar 70:30. Hanya dua desa yang memiliki skor dibawah 3 untuk kedua poin penilaian ini. Sedangkan alokasi dana untuk 3 program prioritas pemberdayaan masyarakat yang dinilai pada poin A4, A5 dan A6 berbanding terbalik dengan 3 poin penilaian sebelumnya. Hanya satu desa yang tercatat konsisten memiliki skor antara 3 dan 4 untuk ketiga poin penilaian ini. Proporsi pengalokasian dana untuk ketiga program pemberdayaan masyarakat ini masih rendah untuk kebanyakan desa yang diteliti. Ketiga program yang dimaksud adalah Program Peningkatan Kapasitas Masyarakat Desa dalam Berwirausaha, Peningkatan Pendapaan atau Perluasan Skala Ekonomi Masyarakat Desa, Program Pelayanan dan Pemberdayaan Kaum Miskin serta Program Pengembangan Potensi Aset dan Budaya Desa.

Dalam Dimensi Pembangunan Sarana Prasaran Desa, terlihat bahwa Dana Desa cenderung difokuskan untuk pendanaan pembangunan Sarpras Transportasi seperti jalan desa. Dari 15 desa yang masuk dalam sampel, semuanya tercatat melaksanakan pembiayaan untuk sarpras jenis ini. Alokasi dana untuk sarpras jenis ini sangat besar karena biaya yang tinggi untuk pembuatan ataupun perbaikan jalan. Pembangunan Sarpras Ekonomi hanya tercatat dilakukan oleh 2 desa. Permasalahan yang ditemui untuk pembangunan sarpras jenis ini adalah beberapa desa yang ada di satu wilayah yang berdekatan cenderung hanya memiliki 1 pasar. Biaya yang besar untuk pembangunan pasar yang baru, orang-orang lebih terbiasa untuk mengunjungi dan berjualan di pasar yang sudah ada menjadi masalah yang dilihat sehingga pemerintah desa tidak melihat pembangunan sarpras ini sebagai suatu prioritas. Adapun pengadaan dana untuk program jenis ini cenderung untuk mengembangkan pasar yang sudah ada.

Pembangunan Sarpras Ketahanan Pangan didanai khususnya desa-desa yang bergantung pada hasil pertanian dan perkebunan sehingga tercatat hanya 6 dari 15 desa yang mendanai sarpras jenis ini. Ada 9 desa yang mendanai Sarpras Pelayanan Dasar dan 8 desa mendanai Sarpras Sistem Informasi Desa, Peta Sosial Digital, Pengembangan Teknologi Terbarukan dan Pengembangan Energi Terbarukan. Pendanaan atau permodalan bagi BUMDesa atau BUMADesa merupakan program kedua setelah Sarpras Transportasi yang paling banyak didanai pemerintah desa. Total ada 14 desa yang melaksanakan pendanaan BUMDes atau BUMADesa. 12 desa tercatat mendanai Sarpras Penyelenggaraan PAUD dan Posyandu. Sarpras Perpustakaan Desa dan Sanggar Belajar serta Sarpras Pengembangan Seni dan Buda Desa masing-masing didanai oleh 6 dari 15 desa yang diteliti. Hanya 2 desa yang mendanai Sarpras Gerakan Desa Menanam dan tidak ada desa yang mendanai Sarpras Budidaya Obat Tradisional.

Fokus Dana Desa tahun 2017 adalah pada Pembangunan Sarana Prasarana Desa. Alokasi dana yang lebih kecil untuk Dimensi Pemberdayaan Masyarakat membuat desa-desa yang diteliti cenderung tidak banyak mendanai program pemberdayaan masyarakat. Dari total nilai rata-rata maksimal yang dapat diperoleh adalah 4, desa-desa di Kabupaten Minahasa Utara hanya mencatatkan skor 1,76, Minahasa Selatan 1,75, dan Minahasa 2,03. Program Peningkatan Kapasitas melalui Pelatihan dan Magang Pengurus BUMDes merupakan jenis program yang paling banyak di danai oleh desa-desa yang diteliti yaitu oleh 11 desa.

Untuk Dimensi Penyelewengan tercatat ada 8 desa yang memakai Dana Desa untuk mendanai program yang tidak menjadi prioritas ataupun yang masuk dalam ketentuan yang ada. Jenis pendanaan yang dilakukan diantaranya membantu mambiayai pembangunan atau perbaikan kantor desa, membantu operasional pemerintah desa, membiayai perjalanan dinas pemerintah desa, membantu membiayai penyelenggaraan kepala desa, dan membiayai SILTAP, gaji, tunjangan maupun honor pemerintah desa dan BPD.

Penelitian ini merekomendasikan beberapa hal. Pertama, pemerintah daerah ataupun pusat harus mensosialisasikan kembali aturan dan ketentuan penggunaan Dana Desa kepada pemerintah desa. Dari hasil yang di dapat, beberapa desa tidak menggunakan Dana Desa seluruhnya untuk kepentingan masyarakat desa dan alokasi untuk Pembangunan Sarana Prasaran Desa dan Pemberdayaan Masyarakat Desa juga belum sesuai dengan rasio 
70:30 seperti yang dianjurkan dalam aturan. Sosialisasi juga dapat membantu mengatasi penyelewengan yang terjadi, dimana Dana Desa digunakan untuk mendanai program yang bukan menjadi prioritas dan tidak sesuai dengan aturan yang ada. Kedua, pemerintah desa masih terfokus menggunakan Dana Desa untuk membangun Sarpras Transportasi seperti jalan desa yang menjadi infrastruktur desa. Pembangunan infrastruktur ini memakan biaya yang tinggi sehingga program-program prioritas lainnya belum bisa didanai. Pemerintah pusat harus melanjutkan pemberian dana transfer dalam bentuk Dana Desa pada periode berikutnya sehingga dana yang didapat pada periode berikutnya dapat dialokasikan oleh pemerintah desa untuk program prioritas yang belum sempat didanai. Manfaat yang besar bagi masyarakat desa juga menjadi pertimbangan program Dana Desa harus diteruskan. Ketiga, pemerintah desa harus mulai memikirkan program pembangunan lain selain sarpras transportasi yang menjadi fokus saat ini. Pembangunan sarpras lainnya akan menghasilkan manfaat yang lebih besar untuk masyarakat desa ketika sarpras transportasi atau infrastruktur sudah terpenuhi. Pendanaan untuk BUMDes dilaksanakan oleh hampir semua desa yang diteliti sehingga pemerintah desa harus mengembangkan BUMDes yang ada. BUMDes yang dikelola dengan baik akan mampu meningkatkan pendapatan asli desa yang. Program pelatihan dan magang untuk pengurus BUMDes harus ditingkatkan sehingga menghasilkan sumber daya manusia yang kompeten.

\section{DAFTAR PUSTAKA}

Kementerian Desa, Pembangunan Daerah Tertinggal dan Transmigrasi Republik Indonesia, 2016. Dana Desa Untuk Desa Membangun Indonesia (Tanya Jawab Seputar Dana Desa), Jakarta

Peraturan Menteri Desa PDTT No 5 Tahun 2015 Tentang Penetapan Prioritas Penggunaan Dana Desa

Peraturan Menteri Desa PDTT No 21 Tahun 2015 tentang Penetapan Prioritas Penggunaan Dana Desa Tahun 2016

PMK Nomor 247/PMK.07/2015 tentang Tata Cara Pengalokasian, Penyaluran, Penggunaan, Pemantauan, dan Evaluasi Dana Desa

PMK Nomor 49/PMK.07/2016 tentang Tata Cara Pengalokasian, Penyaluran, Penggunaan, Pemantauan dan Evaluasi Dana Desa

PP Nomor 60 Tahun 2014 tentang Dana Desa yang Bersumber dari Anggaran Pendapatan dan Belanja Negara

Schadewitz, N. dan Jachna, T., 2007. Comparing Inductive and Deductive Methodologies for Design Patterns Identification and Articulation, School of Design, Core A, The Hong Kong Polytechnic University, Hung Hom, Hong Kong,

Undang-Undang No. 6 Tahun 2014 tentang Dana Desa 